\title{
Effect of starchy or fibrous carbohydrate supplementation of orchardgrass on ruminal fermentation and methane output in continuous culture
}

\author{
K. J. Soder, ${ }^{* 1}$ A. F. Brito, $†$ A. N. Hafla, ${ }^{*}$ and M. D. Rubano* \\ *USDA-Agricultural Research Service, Pasture Systems and Watershed Management Research Unit, University Park, PA $16802-3702$ \\ †Department of Biological Sciences, University of New Hampshire, Durham 03824
}

\begin{abstract}
A 4-unit dual-flow continuous culture fermentor system was used to assess the effects of supplementing orchardgrass (Dactylis glomerata L.) with 2 levels [5 and $10 \%$ of total dry matter (DM) fed] of starchy (barley grain, BAR) or fibrous (beet pulp, BP) carbohydrate sources on nutrient digestibility, volatile fatty acid (VFA) production, bacterial protein synthesis, and $\mathrm{CH}_{4}$ output. Treatments were randomly assigned to fermentors in a $4 \times 4$ Latin square design with a $2 \times$ 2 factorial arrangement using $7 \mathrm{~d}$ for microbial adaptation and $3 \mathrm{~d}$ for sample collection. Treatments included (1) $57 \mathrm{~g}$ of DM orchardgrass $+3 \mathrm{~g}$ of DM BAR, (2) $54 \mathrm{~g}$ of DM orchardgrass $+6 \mathrm{~g}$ of DM BAR, (3) $57 \mathrm{~g}$ of DM orchardgrass $+3 \mathrm{~g}$ of DM BP, or (4) $54 \mathrm{~g}$ of DM orchardgrass $+6 \mathrm{~g}$ of DM BP. Feedings occurred at 0900, 1030, 1400, and $1900 \mathrm{~h}$ throughout four 10-d periods. Gas samples for $\mathrm{CH}_{4}$ analysis were collected 6 times daily at $0725,0900,1000,1355,1530$, and $1630 \mathrm{~h}$. Fermentor samples for $\mathrm{pH}, \mathrm{NH}_{3}-\mathrm{N}$, and VFA analysis were taken on d 8, 9, and 10. Samples were also analyzed for DM, organic matter, crude protein, purines, neutral detergent fiber, and acid detergent fiber to determine nutrient digestibilities and estimation of bacterial protein synthesis. Apparent and true DM and organic matter digestibilities were not affected by supplement source. Apparent neutral and acid detergent fiber digestibilities were greater for BAR than BP. Conversely, apparent crude protein digestibility was greater for $\mathrm{BP}$ than BAR. Mean and maximum $\mathrm{pH}$ tended to be greatest for BAR than BP. Minimum $\mathrm{pH}$ was greater at the lower level ( $5 \%$ of diet DM) of supplementation. Barley produced greater concentrations of total VFA and acetate, whereas BP had greater daily outputs of $\mathrm{CH}_{4}$. Significant supplement type $\times$ level interactions were found for bacterial $\mathrm{N}$ flow and efficiency. Overall, supplementing orchardgrass with BP improved crude protein digestibility, reduced fiber digestibility and
\end{abstract}

Received September 30, 2015.

Accepted March 1, 2016.

${ }^{1}$ Corresponding author: Kathy.Soder@ars.usda.gov total VFA concentration, but increased $\mathrm{CH}_{4}$ output compared with BAR.

Key words: barley, beet pulp, continuous culture fermentation, grazing

\section{INTRODUCTION}

High-quality pastures, such as those found on grazing dairy farms in the northeastern United States, often contain high concentrations of $\mathrm{CP}$, much of which is NPN. Rapid and extensive degradation of CP in orchardgrass occurs in the rumen, and a portion of this soluble $\mathrm{N}$ is absorbed as $\mathrm{NH}_{3}-\mathrm{N}$ through the ruminal wall with some portion subsequently excreted in the urine as urea, thereby reducing utilization of RDP. Energy supplementation of grass can increase the flow of NAN to the duodenum (García et al., 2000), reduce ruminal $\mathrm{NH}_{3}-\mathrm{N}$ concentration (van Vuuren et al., 1986; Bargo et al., 2002), and improve milk production (Stockdale et al., 1987; Kellaway and Porta, 1993; Stockdale, 1999). Supplementation with cereal grains, which are high in starch, shifts ruminal fermentation toward more propionate, positively influencing the energetic status of the cow. However, previous studies have demonstrated adverse effects on ruminal fermentation of fiber when energy in the form of starch is supplemented to highforage diets (El-Shazly et al., 1961; Mould and Orskov, 1984; Miller and Muntifering, 1985). van Vuuren et al. (1990) suggested that feeds containing a high fraction of insoluble, fermentable carbohydrates (such as beet pulp) may be a more suitable supplement for pasture-based diets than supplements such as barley, oats, and wheat, which have a greater proportion of starch. Beet pulp has been shown to have lower ruminal escape of OM than corn, meaning that beet pulp may provide increased energy for microbial growth to improve $\mathrm{NH}_{3}-\mathrm{N}$ uptake in the rumen (van Vuuren et al., 1993). Compared with no supplementation or supplementation with a starchy energy source, several studies reported increased $\mathrm{N}$ utilization in the rumen and increased efficiency of microbial protein synthesis when beet pulp was supplemented to grass-based diets in vitro (Mount et al., 2009) and in vivo [e.g., grazing 
dairy cows (O'Mara et al., 1997) and grazing lambs (Mount et al., 2009)]. However, others have reported no effect of fibrous carbohydrate supplementation on $\mathrm{N}$ utilization in grazing dairy cows (e.g., Pulido et al., 2010).

To the best of our knowledge, no studies have directly compared supplementation of starchy versus fibrous sources of carbohydrate to a grass diet on ruminal fermentation and $\mathrm{CH}_{4}$ production. Therefore, the objective of this study was to evaluate the effects of supplementing orchardgrass with 2 levels (5 or $10 \%$ of total DM fed) of starchy (barley grain, BAR) or fibrous (beet pulp, BP) carbohydrates on nutrient digestibility, VFA production, bacterial protein synthesis, and $\mathrm{CH}_{4}$ output in continuous culture. We hypothesized that compared with BAR, BP supplementation of orchardgrass would improve ruminal fermentation through a more synchronous supply of fermentable energy relative to RDP in the orchardgrass.

\section{MATERIALS AND METHODS}

\section{Site, Experimental Design, and Treatments}

This study was conducted at the USDA-Agricultural Research Service (ARS) Pasture Systems and Watershed Management Research Unit (University Park, PA) from February to April 2014. Orchardgrass (Dactylis glomerata L.) was harvested in the afternoon of September 2, 2011, at the Russell Larson Agricultural Research Farm (Rock Springs, PA) from a pure stand. A forage plot harvester (HEGE 212, Wintersteiger AG, Waldenburg, Germany; 1.5-m-wide swatch) was used for harvesting, set at $10 \mathrm{~cm}$ above soil level, approximately 3 wk after the previous cutting such that resulting orchardgrass was in a vegetative stage of growth, typical of high-quality pastures used for grazing in the northeastern United States (25 to $30 \mathrm{~cm}$ tall). Within 30 min of harvest, the orchardgrass was placed in cloth bags and frozen $\left(-4^{\circ} \mathrm{C}\right)$ until being freeze-dried (Ultra 35 Super ES; VirTis Co. Inc., Gardiner, NY). Barley (Hordeum vulgare L.) used for the barley supplement was a winter hullless variety purchased from Lakeview Organic Grain (Penn Yan, NY). Beet pulp pellets (Standlee Western) were purchased from Tractor Supply Company (State College, PA). Freeze-dried orchardgrass, barley and beet pulp were ground to pass through a 2-mm screen (Wiley mill, Thomas Scientific Inc., Swedesboro, NJ) to be used as feed for the fermentors. While it is recognized that freeze-dried forages are not nutritionally identical to fresh forages, the forage needed to be preserved and ground for use in this experiment, and Jones and Bailey (1972) reported that oven-drying forages could denature protein in plant material, thereby depressing nutrient digestibility.

Total DM (orchardgrass plus supplement) fed to all fermentors was maintained at a constant $60 \mathrm{~g}$ of DM/d for the duration of each period. Supplements (BAR or BP) made up 5 or $10 \%$ of diet DM and were as follows: (1) $57 \mathrm{~g}$ of DM orchardgrass $+3 \mathrm{~g}$ of DM BAR, (2) $54 \mathrm{~g}$ of DM orchardgrass $+6 \mathrm{~g}$ of DM BAR, (3) $57 \mathrm{~g}$ of DM orchardgrass $+3 \mathrm{~g}$ of DM BP, or (4) $54 \mathrm{~g}$ of DM orchardgrass $+6 \mathrm{~g}$ of DM BP. Freeze-dried orchardgrass was fed in equal portions daily $(0730,1030$, 1400, and $1900 \mathrm{~h}$ ), and BAR and BP supplements were fed twice daily (0730 and $1400 \mathrm{~h}$ ) in equal portions to simulate typical supplementation practices that are becoming more common in grazing dairy herds that are reducing the use of concentrates due to increased feed costs, farmer philosophy, or milk price incentives in the northeastern United States. Representative samples of freeze-dried orchardgrass, BAR, and BP were stored for later nutrient analysis. Nutrient analyses of dietary ingredients and treatments were obtained from chemical analyses conducted at a commercial laboratory (Dairy One Laboratories, Ithaca, NY; Table 1) before the start of the study.

\section{Continuous Culture Operation}

This study was a $4 \times 4$ Latin square design with a $2 \times 2$ factorial arrangement of treatments. Feeds were incubated in a 4-unit dual flow continuous culture fermentor system (OmniCulture Plus, VirTis Co. Inc.), similar to that described by Hoover et al. (1989), with the following modifications: $\mathrm{pH}$ was not controlled, feed ingredients were not pelleted, fermentor volumes ranged from 1,100 to $1,140 \mathrm{~mL}$, and urea was added to the mineral buffer solution at a rate of $0.4 \mathrm{~g} / \mathrm{L}$ to simulate recycled N (Weller and Pilgrim, 1974). Solid mean retention time, solid dilution rate, and liquid dilution rate of the fermentors were adjusted daily to approximately $24 \mathrm{~h}, 4 \% / \mathrm{h}( \pm 0.32 \%)$, and $11 \% / \mathrm{h}( \pm 0.41)$, respectively, and were achieved by regulation of buffer input and filtrate removal (Bargo et al., 2003).

Ruminal fluid and digesta samples were collected from a ruminally fistulated, nonlactating, multiparous Holstein cow $(\mathrm{BW}=652 \mathrm{~kg})$ cared for in accordance with the Pennsylvania State University Animal Care and Use (Institutional Animal Care and Use Committee \#39513) guidelines. The donor cow was group housed and fed a diet of mixed grain and grass hay (65:35 forage-to-concentrate ratio) in a feed bunk for a total of $16.2 \mathrm{~kg}$ of DM of available feed per cow per day at the Pennsylvania State University Dairy Research Farm (University Park, PA). The mixed grain 
Table 1. Chemical composition (\% of DM) of diet ingredients and orchardgrass supplemented with barley grain (BAR) or beet pulp (BP) at 2 levels of supplementation ( $5 \%$ or $10 \%$ of total DM fed) during continuous culture fermentation

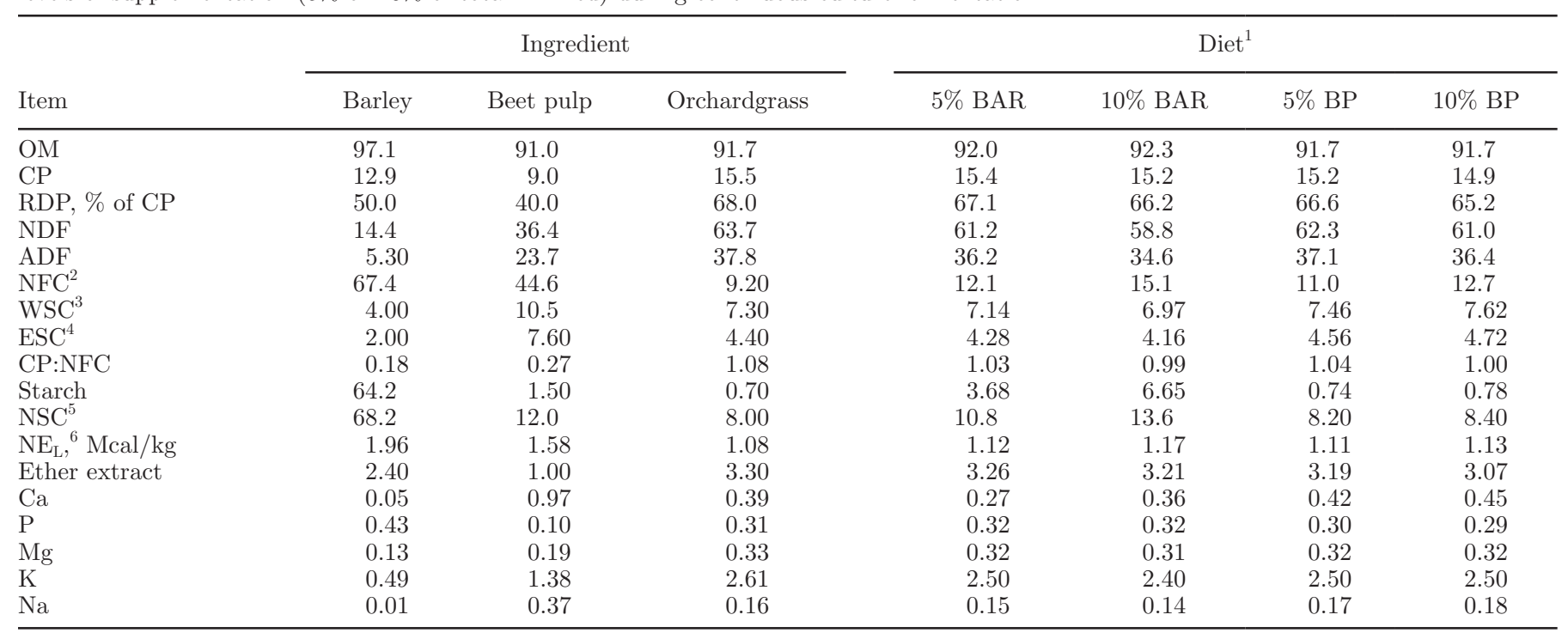

${ }^{1}$ Calculated using actual nutrient composition and proportion of individual ingredients; barley (BAR) or beet pulp (BP) supplemented to orchardgrass at 5 or $10 \%$ of total DM fed.

${ }^{2}$ Calculated as NFC $=100-(\mathrm{CP} \%+\mathrm{NDF} \%+$ ether extract $\%+$ ash \% $)$.

${ }^{3} \mathrm{WSC}=$ water-soluble carbohydrates.

${ }^{4} \mathrm{ESC}=$ ethanol-soluble carbohydrate.

${ }^{5} \mathrm{NSC}=\mathrm{WSC}+$ starch.

${ }^{6}$ Estimated by the NRC (2001) model.

contained a vitamin/mineral premix with the following composition (\% as-is basis): trace mineral mix, 0.86; $\mathrm{MgO}(56 \% \mathrm{Mg}), 8.0 ; \mathrm{NaCl}, 6.4$; vitamin ADE premix, 0.48 ; limestone, 37.2; selenium premix, 0.07; and dry corn distillers grains with solubles, 46.7. Ca, 14.1\%; P, $0.39 \%$; $\mathrm{Mg}, 4.59 \%$; K, 0.44\%; S, 0.39\%; Se, $6.91 \mathrm{mg} /$ $\mathrm{kg}$; Cu, $362 \mathrm{mg} / \mathrm{kg}$; Zn, 1,085 mg/kg; Fe, $186 \mathrm{mg} / \mathrm{kg}$; vitamin $\mathrm{A}, 276,717 \mathrm{IU} / \mathrm{kg}$; vitamin $\mathrm{D}, 75,000 \mathrm{IU} / \mathrm{kg}$; and vitamin E, $1,983 \mathrm{IU} / \mathrm{kg}$ and was fed at $1.8 \%$ of total DMI. Approximately $3 \mathrm{~h}$ after feeding, $6 \mathrm{~L}$ of ruminal fluid was collected with a hand pump into a prewarmed insulated container. Solid digesta was collected by hand from the ventral, central, and dorsal areas of the rumen. Liquid and whole digesta samples were transported to the USDA-ARS laboratory in separate containers. Within 15 min of collection, fluid was strained through 4 layers of cheesecloth and poured into each of the prewarmed fermentation jars until it cleared the overflow spout. Solid digesta was mixed by hand and $25 \mathrm{~g}$ was added to each fermentor. Each fermentor was continuously purged with $\mathrm{CO}_{2}$ gas at a rate of $20 \mathrm{~mL} / \mathrm{min}$ (model MC50, Alicat Scientific, Tucson, $\mathrm{AZ}$ ) to maintain anaerobiosis and the temperature was maintained at $39^{\circ} \mathrm{C}$. Fermentor contents were continually stirred at a rate of $255 \mathrm{rpm}$. Fermentor $\mathrm{pH}$ was recorded immediately before each of the 4 daily feedings.
Fermentors were operated for 4 consecutive 10-d periods and re-inoculated with fresh rumen fluid at the beginning of each period. Each period consisted of a 7-d adaptation period followed by a 3 -d sampling period. Liquid and solid overflow were collected in 4-L plastic containers. During the 7-d adaptation period, the overflow containers were weighed daily and the contents discarded. After being emptied on d 7 and continuing through d 10, the containers were immersed in a chilled $\left(4^{\circ} \mathrm{C}\right)$ water bath [Pennsylvania State University Agricultural Bio-Engineering Department custom design, stainless steel (dimensions: $2.75 \mathrm{~cm}$ deep $\times 3.5 \mathrm{~cm}$ wide $\times 21.3 \mathrm{~cm}$ long) insulated on the bottom and sides with $1.2 \mathrm{~cm}$ of spray foam insulation] with cold water circulator (model 9005, Polyscience, Niles, IL) and each received $20 \mathrm{~mL}$ of $50 \%$ sulfuric acid daily (after being emptied) to inhibit microbial fermentation. During the last $3 \mathrm{~d}$ of each period, liquid and solid effluent overflows from each fermentor were combined and mixed in a blender (model 38LL52 Waring, Torrington, CT) for $30 \mathrm{~s}$ on the lowest setting and speed controlled further with a PowerStat variable transformer (model 3PN126, Superior Electric, Bristol, CT) set at 35 to achieve a slight vortex in the top $1 \mathrm{~cm}$ of the blender contents. This provided for adequate mixing of sample without too much abrasive agitation. After mixing, a 
100-mL effluent sample was taken and composited over the $3 \mathrm{~d}$ to determine overflow DM. A 50-mL sample of effluent was strained through 8 layers of cheesecloth before a $15-\mathrm{mL}$ sub-sample was placed in a $30-\mathrm{mL}$ plastic bottle for determination of VFA [Varian 3300 Gas Chromatograph (FID detector), Varian 4290 Integrator; Rumen Fermentation Profiling Laboratory, West Virginia University, Morgantown, WV; Supelco, 1975, modified to use a 80/120 Carbopack B-DA/4\% Carbowax 20M column; Erwin et al., 1961] and $\mathrm{NH}_{3}-\mathrm{N}$ (Yang and Varga, 1989). The GC parameters used were $2 \mathrm{~m} \times 2 \mathrm{~mm}$ i.d. glass column packed with 80/120 Carbopack B-DA/4\% Carbowax 20M (catalog no. 1-1889, Supelco Inc.), column temperature of $175^{\circ} \mathrm{C}$, injector temperature of $200^{\circ} \mathrm{C}$, detector temperature of $200^{\circ} \mathrm{C}$, $\mathrm{N}$ gas used as a carrier at a flow rate of $24 \mathrm{~mL} / \mathrm{min}$ and injection volume of $1 \mu \mathrm{L}$. An additional 1,100-mL sample of effluent was composited over the 3-d sample period, freeze-dried, ground to pass through a 1-mm sieve, and stored in a sealed plastic bag at ambient temperature for later analyses of DM, OM, NDF, CP, and total purines. On d 10, in addition to the previously reported sampling, the contents of each fermentor jar were processed according to the methods of Griswold et al. (1996) with the following modification: in lieu of the initial centrifugation, contents were mixed in the blender as described above for $30 \mathrm{~s}$ and strained through 2 layers of $53-\mu \mathrm{m}$ Nitex fabric (Wildco, Buffalo, NY) into a 2-L plastic container with $5 \mathrm{~mL}$ of $50 \%$ sulfuric acid added to retard microbial growth. Contents were then centrifuged 3 times at 20,000 $\times$ $g$ for $20 \mathrm{~min}$ at $-4^{\circ} \mathrm{C}$ with the pellet re-suspended in $0.9 \%$ saline and $50 \%$ methanol, respectively, for the last 2 centrifugations (Griswold et al., 1996). The final pellet was placed in a plastic container and stored in the freezer until subsequent freeze-drying and analyses for DM, OM, and CP [per previously described AOAC International (2006) procedures described in the Nutrient Analyses section below] and purines (Zinn and Owens, 1986). Purine data were used to calculate bacterial efficiencies as described in the Statistical Analysis and Calculations section below.

\section{Methane Collection and Measurements}

Gas samples for $\mathrm{CH}_{4}$ analysis were collected 6 times daily in duplicate $(0725,0900,1000,1355,1530$, and $1630 \mathrm{~h}$ ) using a 25-gauge needle attached to a $30-\mathrm{mL}$ syringe (Vibart et al., 2007). A separate needle and syringe were designated for each fermentor. After the syringe was plunged 3 times to purge any residual gas, the needle was inserted through a rubber septum (part \#608010, Sigma-Aldrich, St. Louis, MO) located in a port on top of the fermentor, and $30 \mathrm{~mL}$ of gas was withdrawn from the headspace. A stopcock attached between the needle and syringe ensured that gas did not escape upon transference to an evacuated $15-\mathrm{mL}$ glass vial through a septum in the cap. Gas samples were analyzed for $\mathrm{CH}_{4}$ using a $\mathrm{GC}$ (Varian CP 3800, Agilent Technologies, Santa Clara, CA) as described in Soder et al. (2012). The daily average of the 6 temporal $\mathrm{CH}_{4}$ samplings (averaged within treatment and across all 3 sampling days) was used in the calculation of mean daily $\mathrm{CH}_{4}$ output (Johnson et al., 2009; see calculation in Statistical Analysis and Calculations section below). For graphing temporal $\mathrm{CH}_{4}$ output (Figure 1), the noncumulative average of $\mathrm{CH}_{4}$ output at each of the 6 individual sampling times was used (averaged within treatment and across all 3 sampling days).

\section{Nutrient Analyses}

Samples of orchardgrass, barley, and beet pulp were analyzed by wet chemistry (Dairy One Laboratories, Ithaca, NY) according to the following sample analyses: DM (method 930.15; AOAC International, 2006), CP (method 990.03; AOAC International, 2006), RDP (Cornell Streptomyces griseus enzymatic digestion; Coblentz et al., 1999), NDF [Ankom model A200; Ankom Technology method 6 (NDF in Feeds-Filter Bag Technique for A200; Ankom Technology, Fairport, NY); solutions as in Van Soest et al. (1991) with heat-stable $\alpha$-amylase and sodium sulfite used in the NDF procedure (inclusive of ash)]. Water-soluble carbohydrates were determined by incubating samples in a $40^{\circ} \mathrm{C}$ water bath for $1 \mathrm{~h}$, extracting WSC (simple sugars and fructan). The WSC was determined using a Thermo Scientific Genesys 10S Vis Spectrophotometer after acid hydrolysis with sulfuric acid (Smith, 1969) using potassium ferricyanide for the colorimetric reaction rather than potassium iodide-potassium oxalate as cited in Smith (1969), as potassium ferricyanide provides a more stable reaction for detecting reducing sugars (Miller-Webster et al., 2002). Ethanol-soluble carbohydrates (Hall et al., 1999), starch (Application Note Number 319; YSI Inc. Life Sciences, Yellow Springs, OH), minerals (Ca, P, $\mathrm{Mg}, \mathrm{K}, \mathrm{Na}$; Thermo IRIS Advantage HX or intrepid inductively coupled plasma radial spectrometer after microwave digestion; CEM Application Note for Acid Digestion, CEM, Matthews, NC), and ether extract (method 2003.05; AOAC International, 2006) were also determined. The NFC concentration was calculated using the equation $\mathrm{NFC} \%=100 \%-(\mathrm{CP} \%+\mathrm{NDF} \%$ + ether extract $\%+$ ash \%). Pectins were included in the NFC calculation but were not included in WSC or NSC analyses.

Effluent samples and microbial pellets were analyzed for DM and OM (methods 930.15 and 942.05, respec- 
tively; AOAC International, 2006) and CP content (micro-Kjeldahl digestion using 75 -mL calibrated tubes with $\mathrm{CuSO}_{4} / \mathrm{K}_{2} \mathrm{SO}_{4}$ catalyst, method 976.06 ; AOAC International, 2006). The NDF content of the effluent was determined using the Ankom model A200 with heat-stable $\alpha$-amylase and sodium sulfite used in the NDF procedure (inclusive of ash; Ankom Technology method 6 (NDF in Feeds - Filter Bag Technique for A200; Ankom Technology, Fairport, NY); solutions as in Van Soest et al. (1991) with heat-stable $\alpha$-amylase and sodium sulfite used in the NDF procedure (inclusive of ash)]. Concentrations of total purines (Zinn and Owens, 1986) in effluent and microbial isolates were used to partition effluent $\mathrm{N}$ flow into microbial and nonmicrobial fractions and to calculate true CP, DM, and $\mathrm{OM}$ digestibilities and flows.

\section{Statistical Analysis and Calculations}

Data were analyzed as a $4 \times 4$ Latin square design with a $2 \times 2$ factorial arrangement of treatments using the PROC MIXED procedure of SAS (SAS Institute Inc., Cary, NC), fitted to the following model:

$$
\mathrm{Y}_{i j k}=\mu+\mathrm{P}_{i}+\mathrm{F}_{j}+\mathrm{T}_{k}+\mathrm{PT}_{i k}+\mathrm{e}_{i j k},
$$

where $Y_{i j k}=$ the observations for dependent variables, $\mu=$ the population mean, $\mathrm{P}_{i}=$ the mean effect of the $i$ th period, $\mathrm{F}_{j}=$ the mean effect of the $j$ th fermentor, $\mathrm{T}_{k}=$ the mean effect of the $k$ th treatment, $\mathrm{PT}_{i k}=$ the interaction between the $i$ th period and $k$ th treatment, and $\mathrm{e}_{i j k}=$ the residual error. Preplanned orthogonal contrasts were used to test the main effect of supplement type (BAR vs. BP), supplement level (5 vs. 10\%), and the supplement source $\times$ supplement level interaction. Period and treatment were fixed effects and fermentor and error were random.

Measures of $\mathrm{CH}_{4}$ concentrations were analyzed for temporal patterns using the following model:

$$
\mathrm{Y}_{i j k l}=\mu+\mathrm{P}_{i}+\mathrm{F}_{j}+\mathrm{T}_{k}+\mathrm{E}_{i j k}+\mathrm{H}_{1}+\mathrm{HT}_{\mathrm{kl}}+\mathrm{E} 2_{i j k l},
$$

where $\mathrm{Y}_{i j k l}=$ the observations for dependent variables, $\mu=$ the population mean, $\mathrm{P}_{i}=$ the mean effect of $i$ th period, $\mathrm{F}_{j}=$ the mean effect of the $j$ th fermentor, $\mathrm{T}_{k}$ $=$ the mean effect of the $k$ th treatment, $\mathrm{E} 1_{i k j}=$ the whole plot error, $\mathrm{H}_{l}=$ the mean effect of the lth hour

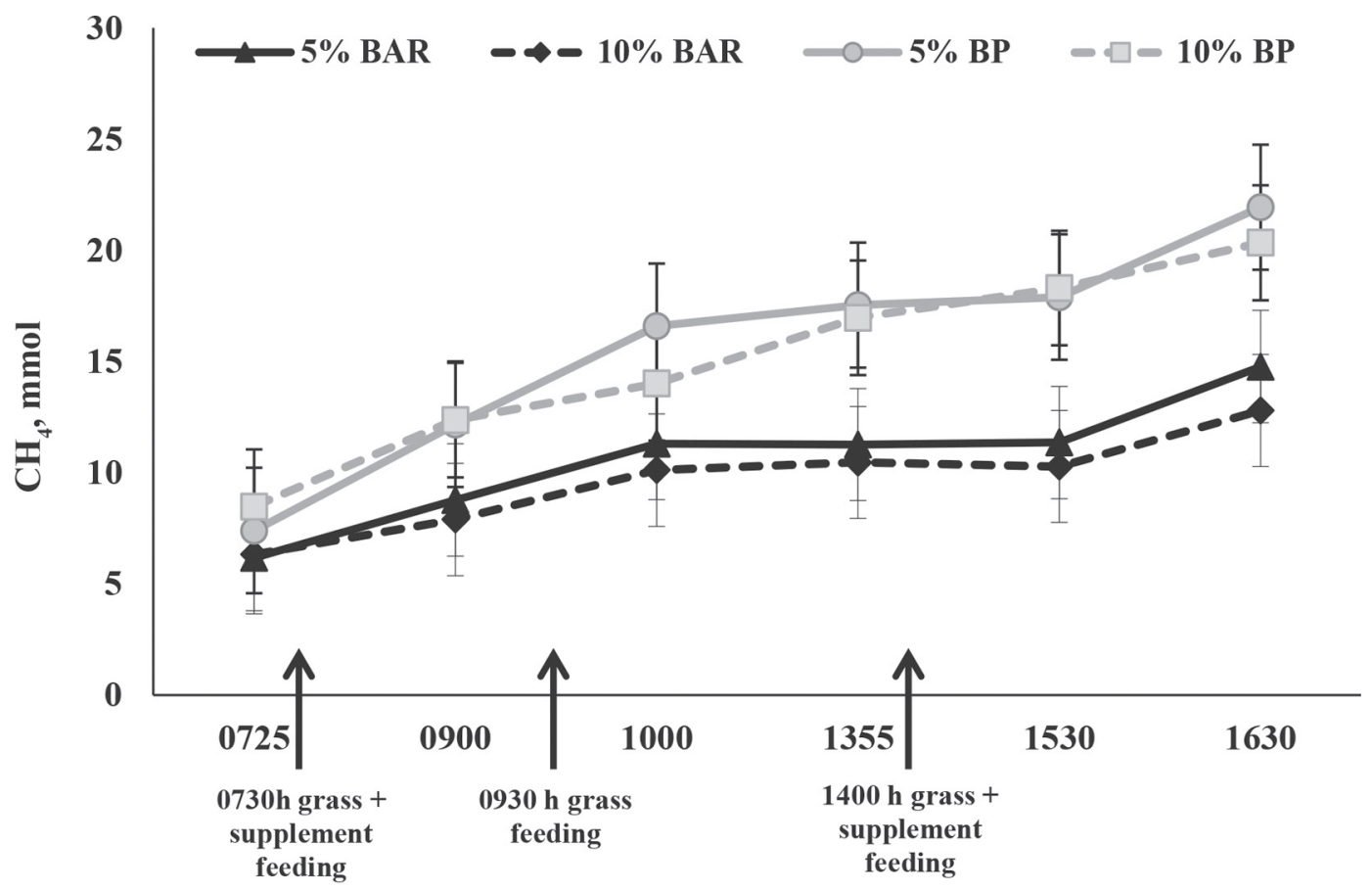

Times of $\mathrm{CH}_{4}$ sampling and feeding

Figure 1. Noncumulative temporal $\mathrm{CH}_{4}$ output of orchardgrass supplemented with barley grain (BAR) or beet pulp (BP) at 2 levels of supplementation ( 5 or $10 \%$ of total DM fed) during continuous culture fermentation. Fermentors were fed (see arrows) at 0730 h (orchardgrass plus supplement), $0930 \mathrm{~h}$ (orchardgrass only), $1400 \mathrm{~h}$ (orchardgrass plus supplement), and $1900 \mathrm{~h}$ (orchardgrass only; not depicted on this figure because no $\mathrm{CH}_{4}$ samples were taken past 1630 h). Methane samples were collected at 0725, 0900, 1000, 1355, 1530, and 1630 h. Error bars represent standard errors. 
sampled analyzed as repeated measures, $\mathrm{HT}_{l k}=$ the interaction between the $l$ th hour and $k$ th treatment, and $\mathrm{E} 2_{i j k l}=$ the subplot residual error. All terms were considered fixed effects except fermentor, whole plot error, and subplot error, which were considered random. An autoregressive covariance structure, which showed the lowest Akaike information criterion values, was retained in the final model.

All reported values are least squares means. Significance was declared at $P \leq 0.05$ and tendencies at $0.05<P \leq 0.10$ for all analyses. No period or period $\times$ treatment interaction effects were found; therefore, only the main effects and supplement $\times$ level interactions were reported.

Apparent (DM, OM, NDF, and ADF) and true (DM, $\mathrm{OM}, \mathrm{CP}$ ) digestibilities of nutrients were calculated as follows (DM as an example):

DM apparently digested $(\%$ of total $\mathrm{DM})=$ [(g of DM fed $-\mathrm{g}$ of effluent flow DM $) \div \mathrm{g}$ of DM fed] $\times 100$, with effluent corrected for $\mathrm{g}$ of buffer DM.

DM truly digested $(\%$ of total DM $)=$ $\{[(\mathrm{g}$ of DM fed $-(\mathrm{g}$ of effluent flow DM $-\mathrm{g}$ of microbial DM) $\div$ g of DM fed $\} \times 100$, with effluent corrected for $g$ of buffer DM.

Nitrogenous fraction flows were calculated as follows:

Total $\mathrm{N}$ intake $(\mathrm{g} / \mathrm{d})=$ infused urea $(\mathrm{g} / \mathrm{d})$

$$
+ \text { dietary } N(\mathrm{~g} / \mathrm{d}) \text {. }
$$

$\mathrm{NH}_{3}-\mathrm{N}$ flow $(\mathrm{g} / \mathrm{d})=\left[\left(\right.\right.$ effluent $\mathrm{NH}_{3}-\mathrm{N}$ in $\mathrm{mg} / \mathrm{dL}$ $\times($ total effluent flow in $\mathrm{mL} \times 1 \mathrm{dL} / 100 \mathrm{~mL})]$.

$$
\text { Non- } \mathrm{NH}_{3}-\mathrm{N} \text { flow }(\mathrm{g} / \mathrm{d})=
$$

(g of total effluent $\mathrm{N}$ flow) - (g of effluent $\left.\mathrm{NH}_{3}-\mathrm{N}\right)$.

Microbial $\mathrm{N}$ flow $(\mathrm{g} / \mathrm{d})=(\mathrm{g}$ of microbial DM $)$ $\times(\% \mathrm{~N}$ in microbes $\div 100)$.

Dietary $\mathrm{N}$ flow $(\mathrm{g} / \mathrm{d})=\left(\mathrm{g}\right.$ of effluent non- $\left.\mathrm{NH}_{3}-\mathrm{N}\right)$ - (g of effluent microbial $\mathrm{N})$.

Total $\mathrm{N}$ flow $(\mathrm{g} / \mathrm{d})=\left(\mathrm{g}\right.$ of effluent $\mathrm{NH}_{3}-\mathrm{N}$ flow $)$

$$
+\left(\mathrm{g} \text { of non- } \mathrm{NH}_{3}-\mathrm{N} \text { flow }\right) \text {. }
$$

Rumen-degradable $\mathrm{N}(\mathrm{mg} / \mathrm{d})=(\mathrm{g}$ of total $\mathrm{N}$ intake $)$

$$
\text { - (g of dietary } \mathrm{N} \text { flow). }
$$

Bacterial efficiency was calculated as follows:

bacterial efficiency ( $\mathrm{mg}$ of bacterial $\mathrm{N} / \mathrm{kg}$

OM truly digested $)=(\mathrm{g}$ of effluent bacterial $\mathrm{N} \div \mathrm{g}$ of OM truly digested) $\times 1,000$, where

effluent bacterial $\mathrm{N}(\mathrm{g})=[$ effluent total $\mathrm{N}(\mathrm{g} / \mathrm{d})$

$\times(\%$ bacterial $\mathrm{N}$ in effluent total $\mathrm{N} / 100)]$, and

$\%$ bacterial $\mathrm{N}$ in effluent total $\mathrm{n}=$ [effluent purine $(\mathrm{mg} / \mathrm{g}$ of $\mathrm{N}) \div$ bacterial purine $(\mathrm{mg} / \mathrm{g}$ of $\mathrm{N})] \times 100$.

Daily $\mathrm{CH}_{4}$ output $(\mathrm{mmol} / \mathrm{d})$ was estimated using the following equation:

$\mathrm{CH}_{4}$ concentration in fermentor headspace $(\mathrm{mmol} / \mathrm{mL})$

$\times \mathrm{CO}_{2}$ gas flow through the fermentor headspace

$$
(20 \mathrm{~mL} / \mathrm{min}) \times 60 \mathrm{~min} \times 24 \mathrm{~h} .
$$

Methane output (mmol/g of OM fed, NDF fed, or digestible NDF or OM fed) were calculated as follows (OM fed used as an example):

mmol of $\mathrm{CH}_{4}$ output/g of $\mathrm{OM}$ fed $=$ [daily $\mathrm{CH}_{4}$ output $(\mathrm{mmol} / \mathrm{d}) / \mathrm{g}$ of $\mathrm{OM}$ fed/d].

\section{RESULTS}

\section{Treatment Composition and Nutrient Digestibility}

Chemical composition of dietary ingredients and treatments are presented in Table 1. The use of pooled samples for compositional analysis of dietary ingredient samples precluded statistical comparison of treatments. The CP of the treatments ranged from $14.9 \%$ for $10 \%$ $\mathrm{BP}$ to $15.4 \%$ for $5 \%$ BAR. The NDF numerically ranged from $58.8 \%$ for $10 \%$ BAR to $62.3 \%$ for $5 \%$ BP with ADF showing similar numerical differences (34.6 and $37.1 \%$ for $10 \% \mathrm{BP}$ and $5 \%$ BAR, respectively). Concentration of NSC ranged from $8.20 \%$ for $5 \%$ BP to $13.6 \%$ for $10 \%$ BAR with starch following a similar numerical difference $(0.74$ and $6.65 \%$ for $5 \% \mathrm{BP}$ and $10 \%$ $\mathrm{BAR}$, respectively). The $\mathrm{NE}_{\mathrm{L}}$ was numerically greater for the $10 \%$ BAR (1.17 vs. 1.11 to $1.12 \mathrm{Mcal} / \mathrm{kg}$ for the other 3 treatments). Additionally, orchardgrass supple- 
Table 2. Nutrient digestibility of orchardgrass supplemented with barley grain (BAR) or beet pulp (BP) at 2 levels of supplementation (5 or $10 \%$ of total DM fed) during continuous culture fermentation

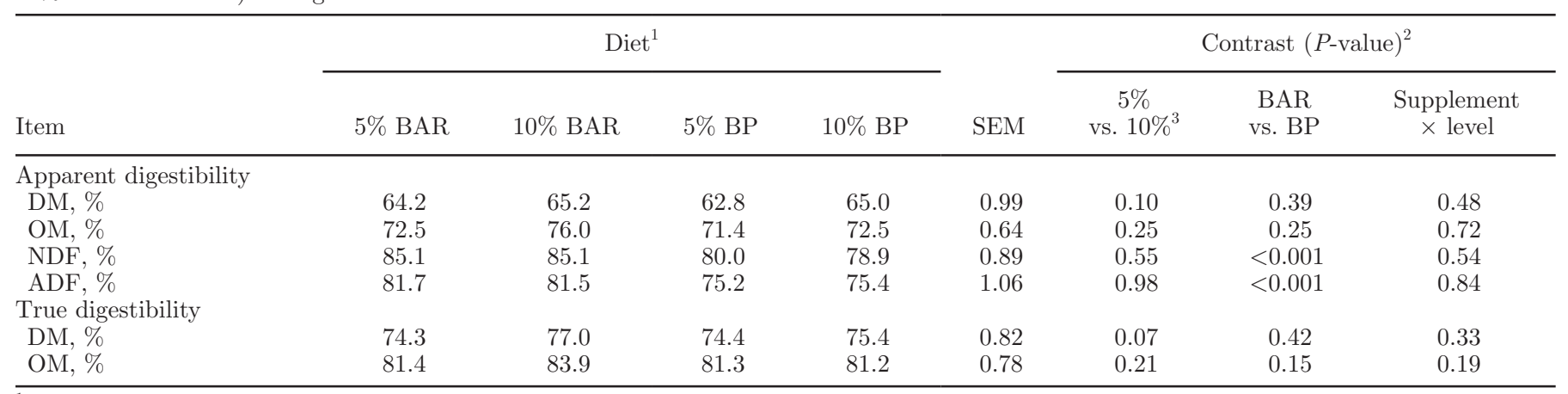

${ }^{1}$ Barley (BAR) or beet pulp (BP) supplemented to orchardgrass at 5 or $10 \%$ of total DM fed.

${ }^{2}$ Significance was declared at $P \leq 0.05$ and tendencies at $0.05<P \leq 0.10$.

${ }^{3}$ Level of supplement as a \% of total DM fed.

mented with BAR had numerically greater starch content (3.68 and 6.65 for $5 \%$ and $10 \%$ BAR, respectively) compared with orchardgrass supplemented with beet pulp ( 0.74 and 0.78 for $5 \%$ and $10 \% \mathrm{BP}$, respectively), whereas orchardgrass supplemented with BP had $10 \%$ (numerically) greater ethanol-soluble carbohydrates than orchardgrass supplemented with BAR (4.64 vs. $4.22 \%$, respectively). Both BAR treatments had $31 \%$ (numerically) greater NSC concentration than the BP treatments (15.4 vs. $11.8 \%$, respectively).
No supplement type $\times$ supplement level interactions were observed for apparent and true nutrient digestibilities (Table 2). Apparent DM and OM digestibilities, as well as true OM digestibility, were not affected by supplement type or level. True DM digestibility tended $(P=0.07)$ to be greater with $10 \%$ versus $5 \%$ of supplementation with either BAR or BP. Whereas apparent NDF and ADF digestibilities were not affected by supplement level, both were greater $(P \leq 0.05)$ for BAR than for BP.

Table 3. Fermentor pH, VFA production, and $\mathrm{CH}_{4}$ output of orchardgrass supplemented with barley grain (BAR) or beet pulp (BP) at 2 levels of supplementation ( $5 \%$ or $10 \%$ of total DM fed) during continuous culture fermentation

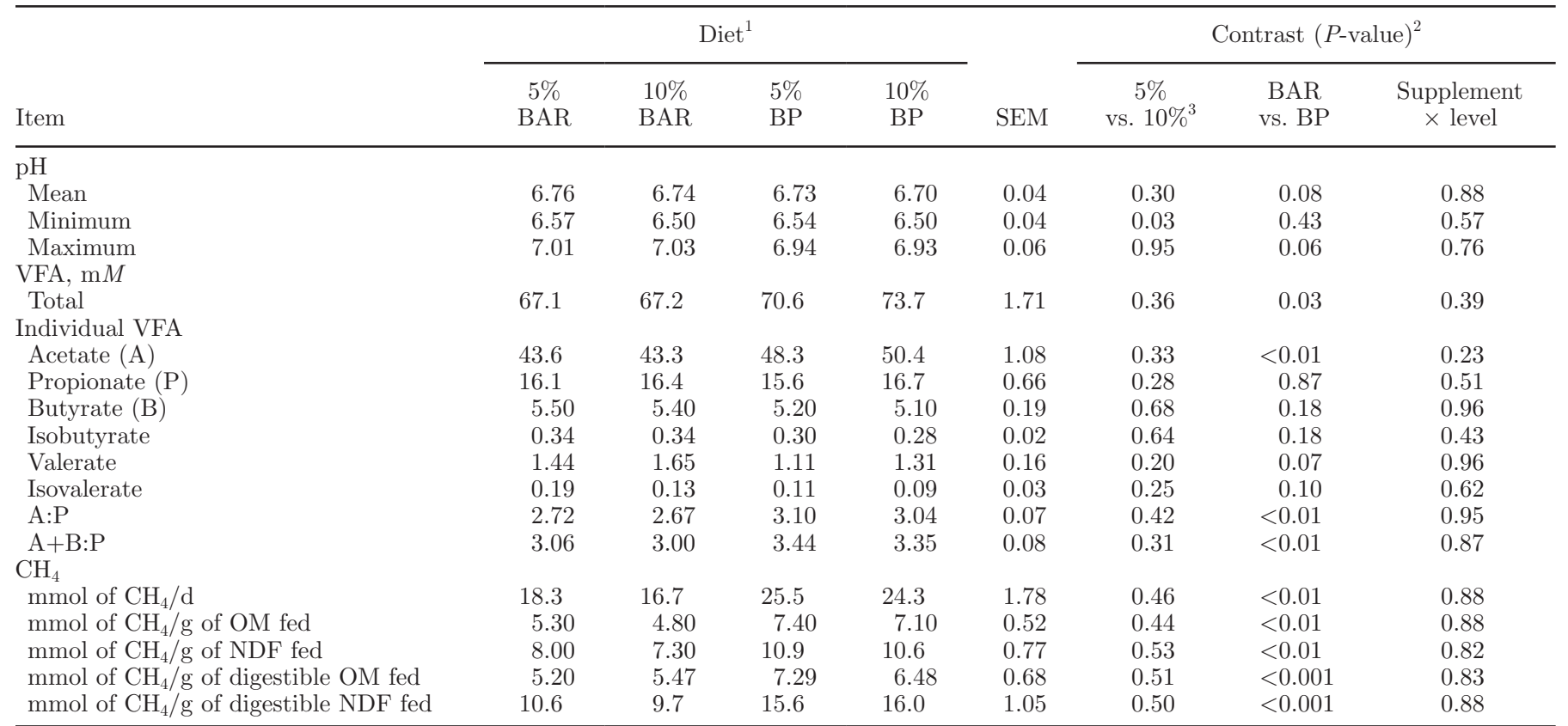

${ }^{1}$ Barley (BAR) or beet pulp (BP) supplemented to orchardgrass at 5 or $10 \%$ of total DM fed.

${ }^{2}$ Significance was declared at $P \leq 0.05$ and tendencies at $0.05<P \leq 0.10$.

${ }^{3}$ Level of supplement as a $\%$ of total DM fed. 
Table 4. Nitrogen metabolism of orchardgrass supplemented with barley grain (BAR) or beet pulp (BP) at 2 levels of supplementation (5 or $10 \%$ of total DM fed) during continuous culture fermentation

\begin{tabular}{|c|c|c|c|c|c|c|c|c|}
\hline \multirow[b]{2}{*}{ Item } & \multicolumn{4}{|c|}{ Diet $^{1}$} & \multirow[b]{2}{*}{ SEM } & \multicolumn{3}{|c|}{ Contrast $(P \text {-value })^{2}$} \\
\hline & $5 \% \mathrm{BAR}$ & $10 \% \mathrm{BAR}$ & $5 \% \mathrm{BP}$ & $10 \% \mathrm{BP}$ & & $\begin{array}{c}5 \% \text { vs. } \\
10 \%^{3}\end{array}$ & $\begin{array}{c}\text { BAR } \\
\text { vs. BP }\end{array}$ & $\begin{array}{l}\text { Supplement } \\
\quad \times \text { level }\end{array}$ \\
\hline $\mathrm{N}$ intake ${ }^{4} \mathrm{~g} / \mathrm{d}$ & 2.00 & 1.97 & 2.02 & 2.00 & 0.01 & 0.01 & $<0.01$ & 0.46 \\
\hline $\mathrm{NH}_{3}-\mathrm{N}, \mathrm{mg}$ of $\mathrm{N} / \mathrm{dL}$ & 13.7 & 12.9 & 14.1 & 13.6 & 0.33 & 0.09 & 0.14 & 0.63 \\
\hline True CP digestibility, \% & 49.0 & 56.0 & 75.4 & 75.2 & 2.53 & 0.26 & $<0.001$ & 0.24 \\
\hline \multicolumn{9}{|l|}{$\mathrm{N}$ flows, $\mathrm{g} / \mathrm{d}$} \\
\hline NAN & 1.12 & 1.10 & 0.83 & 0.78 & 0.04 & 0.38 & $<0.001$ & 0.82 \\
\hline Bacterial N & 0.41 & 0.47 & 0.47 & 0.42 & 0.02 & 0.71 & 0.81 & 0.03 \\
\hline Dietary N & 0.74 & 0.63 & 0.37 & 0.36 & 0.04 & 0.19 & $<0.001$ & 0.21 \\
\hline \multicolumn{9}{|l|}{ Bacterial efficiency } \\
\hline $\mathrm{g}$ of $\mathrm{N} / \mathrm{kg}$ of $\mathrm{OM}$ truly digested & 9.69 & 10.8 & 11.0 & 9.87 & 0.41 & 0.92 & 0.62 & 0.04 \\
\hline
\end{tabular}

${ }^{1}$ Barley (BAR) or beet pulp (BP) supplemented to orchardgrass at 5 or $10 \%$ of total DM fed.

${ }^{2}$ Significance was declared at $P \leq 0.05$ and tendencies at $0.05<P \leq 0.10$.

${ }^{3}$ Level of supplement as a $\%$ of total DM fed.

${ }^{4} \mathrm{~N}$ intake $(\mathrm{g} / \mathrm{d})=\operatorname{dietary} \mathrm{N}(\mathrm{g} / \mathrm{d})+$ urea-N from buffer $(\mathrm{g} / \mathrm{d})$.

\section{Fermentor pH, VFA, and Methane Output}

No supplement type $\times$ supplement level interactions were observed for mean, minimum, and maximum fermentor $\mathrm{pH}$ (Table 3). Minimum fermentor $\mathrm{pH}$ was greater $(P=0.025)$ with $5 \%$ versus $10 \%$ supplementation. Mean and maximum fermentor $\mathrm{pH}$ tended $(P=$ 0.08 and $P=0.06$, respectively) to be greater for BAR than for BP.

No supplement type $\times$ supplement level interactions were observed for concentrations of total or individual VFA or ratios of VFA (Table 3). No effect was found of supplement level on total VFA concentration, individual VFA concentrations, or ratios of VFA. Total VFA and acetate concentrations were greater $(P<0.05)$ for $\mathrm{BP}$ than for BAR. Valerate concentrations tended $(P$ $=0.07$ ) to be greater for BAR than for BP treatments. The ratio of acetate to propionate, and the ratio of acetate plus butyrate to propionate were greater $(P<$ 0.05 ) for BP than for BAR, primarily due to the shift in acetate.

No supplement type $\times$ supplement level interactions were observed for $\mathrm{CH}_{4}$ output expressed as millimoles per day (Table 3). Methane output was lowest for all treatments when sampled immediately before the 0730 $\mathrm{h}$ feeding of orchardgrass and supplement, and increased $(P<0.05)$ throughout the day when expressed as daily $\mathrm{CH}_{4}$ output (Figure 1), millimoles per gram of OM fed, NDF fed, or digestible NDF and OM fed (data not shown for these last 4 variables). Temporal patterns showed a treatment by sampling time interaction $(P=$ 0.054) for daily $\mathrm{CH}_{4}$ output for all treatments (Figure $1)$. The BP treatments had a greater increase in $\mathrm{CH}_{4}$ output between samplings than did BAR. This resulted in BP having significantly greater $\mathrm{CH}_{4}$ output at the 1355, 1530, and 1630 samplings than BAR.

No effect was found of supplement level on any of the $\mathrm{CH}_{4}$ output variables. Orchardgrass supplemented with BP had greater $(P<0.01)$ output of daily $\mathrm{CH}_{4}$, as well as greater $(P<0.05) \mathrm{CH}_{4}$ output when expressed as millimoles per gram of $\mathrm{OM}$ fed, NDF fed, or digestible NDF or OM fed compared with orchardgrass supplemented with BAR.

\section{Nitrogen Metabolism}

No supplement type $\times$ supplement level interactions were found for $\mathrm{N}$ intake, $\mathrm{NH}_{3}-\mathrm{N}$ concentration, true $\mathrm{CP}$ digestibility, and nitrogenous fractions flows (i.e., total $\mathrm{N}, \mathrm{NH}_{3}-\mathrm{N}, \mathrm{NAN}$, and dietary $\mathrm{N}$ flow; Table 4). However, significant $(P<0.05)$ supplement type $\times$ supplement level interactions were found for bacterial $\mathrm{N}$ flow and bacterial efficiency (mg of bacterial $\mathrm{N} / \mathrm{kg}$ of OM truly digested). Nitrogen intake was greater $(P$ $<0.01)$ at the lower level of supplementation, whereas $\mathrm{NH}_{3}-\mathrm{N}$ concentration tended $(P=0.10)$ to be greater at the lower level of supplementation. Nitrogen intake and true $\mathrm{CP}$ digestibility were greater $(P<0.05)$ for $\mathrm{BP}$ than for BAR. Total N, NAN, and dietary N flows were greater $(P<0.05)$ for BAR than for BP.

\section{DISCUSSION}

\section{Treatment Composition}

Crude protein and NDF values were typical of feed-grade barley and beet pulp (NRC, 2001). Nutrient concentration of the forage used in this study 
was considered moderate quality with $\mathrm{CP}$ of $15 \%$ and moderately high NDF concentrations (64\%; Bargo et al., 2003). The nutrient content of the treatments reflects that of the ingredients. For example, the CP of the barley-supplemented treatments was an average of 0.2 percentage units greater than the beet pulp-supplemented treatments due to the increased $\mathrm{CP}$ of the barley supplement compared with the beet pulp supplement (12.9 and 9.0\%, respectively). The greater starch content of the barley supplement (60.2 vs. $1.5 \%$ for beet pulp) resulted in a 5- to 9-fold numerical increase in starch values for the barley-supplemented treatments compared with beet pulp-supplemented treatments.

\section{Nutrient Digestibility}

Apparent DM and $\mathrm{OM}$ digestibilities ranged from 62.8 to $65.2 \%$ and 71.4 to $76.0 \%$, respectively, across treatments. These values are in general agreement with previously reported values for perennial ryegrass (Lolium perenne L.)- and orchardgrass-only treatments fermented in continuous culture, with apparent DM and $\mathrm{OM}$ digestibilities ranging from 49 to $70.2 \%$ and 58 to $72.4 \%$, respectively (de Veth and Kolver, 2001; Bargo et al., 2003; Soder et al., 2012). Although supplement type did not affect apparent or true DM and OM digestibilities, apparent NDF and ADF digestibilities were greater for BAR than for BP. The increased digestion of fiber fractions and slightly lesser amounts of NDF to digest in BAR may be explained by a greater concentration of starch compared with $\mathrm{BP}$ (average of 5.17 vs. $0.76 \%$, respectively, for BAR and BP) and, as a result, more fermentable energy available to stimulate cellulolytic bacteria growth. For instance, replacing dietary starch with neutral detergent-soluble fiber (12.7, $16.4,20.1$, or $23.8 \%$ NDSF, DM basis) by inclusion of sugar beet pulp increased carboxymethylcellulase and xylanase activities in the solid fraction and apparent disappearance of ADF, but decreased the $16 \mathrm{~S}$ rDNA copy numbers of Ruminococcus albus in both liquid and solid fractions and Ruminococcus flavefaciens in the solid fraction using the rumen simulation technique apparatus (Zhao et al., 2013). Nutritional interdependence or "cross-feeding" among key ruminal microorganisms involved in starch and fiber utilization such as Ruminobacter amylophilus (former Bacteroides amylophilus), Megasphaera elsdenii, and Ruminococcus albus as reported by Miura et al. (1980) should be also considered to explain current results.

\section{Fermentor pH, VFA, and Methane Output}

Barley tended to produce greater mean and maximum fermentor $\mathrm{pH}$ than BP. The $10 \%$ level of supplementa- tion resulted in lower minimum $\mathrm{pH}$ than the $5 \%$ level of supplementation, which may be explained by the additional amount of fermentable energy provided with the greater supplementation rate (Dixon and Stockdale, 1999). However, minimum fermentor $\mathrm{pH}$ was greater than 6.4 for all treatments, which has been shown to be the optimal $\mathrm{pH}$ for cellulose digestion (Hoover, 1986; Wales et al., 2004).

The VFA results reported in this study are within range of those reported in other continuous culture fermentation studies evaluating grass diets supplemented with beet pulp (Bach et al., 1999) or barley (Fellner et al., 2008; Wales et al., 2009). Total VFA and acetate concentrations were greater for BP than for $\mathrm{BAR}$, whereas valerate tended to be greater for BAR than for BP. Total VFA results in the present study are corroborated by previous studies in which readily digestible fiber sources such as beet pulp were fed (Grigsby et al., 1992; Carey et al., 1993). The greater proportion of acetate observed in the BP treatments was not surprising as ruminal acetate is derived primarily from the fermentation of structural carbohydrates (Feng et al., 1995). Fermentation of pectin by known pectinolytic bacteria strains (e.g., Prevotella ruminicola and Butyrivibrio fibrisolvens) yielded acetate as the major end product, whereas butyrate, formate, or lactate were produced when glucose was used as a substrate (Marounek and Dušková, 1999; Dušková and Marounek, 2001). Liu et al. (2015) reported that when comparing corn stover plus citrus peel pectin with corn stover plus corn starch, as well as pectin with starch, pectin supplementation increased acetate production, whereas starch increased butyrate production during an in vitro study using mixed rumen microbial populations. In the current study, fiber digestibility decreased despite increased acetate production with feeding beet pulp. These results suggest that pectin from beet pulp led to more acetate production than barley or fiber from orchardgrass or both. Ariza et al. (2001) demonstrated in continuous culture that citrus pulp (rich in pectin) resulted in greater acetate concentrations than hominy feed (rich in starch) without an effect on butyrate formation, which agrees with our results. Strobel and Russell (1986) found increased acetate production with pectin than with other carbohydrate sources, with little effect on propionate production, which agrees with the results of the current study.

A significant supplementation type $\times$ level of supplementation interaction was found for $\mathrm{CH}_{4}$ output. The lowest $\mathrm{CH}_{4}$ output was observed for all treatments when sampled immediately before the first daily feeding of forage and supplement (Figure 1). This observation was likely due to depletion of substrate in the continuous culture system, as the previous feeding (forage only) 
occurred $12 \mathrm{~h}$ prior. All treatments increased in $\mathrm{CH}_{4}$ output throughout the day, which has been shown by others (e.g., Hafla et al., 2014; Brask et al., 2015).

Beet pulp produced $42 \%$ more $\mathrm{CH}_{4} \quad(\mathrm{mmol} / \mathrm{d})$ than BAR. Moreover, BP produced more $\mathrm{CH}_{4}$ when expressed as millimoles of $\mathrm{CH}_{4}$ per gram of $\mathrm{OM}$ fed, millimoles of $\mathrm{CH}_{4}$ per gram of NDF fed, millimoles of $\mathrm{CH}_{4}$ per gram of digestible NDF fed, and millimoles of $\mathrm{CH}_{4}$ per gram of digestible OM fed than BAR. Greater $\mathrm{CH}_{4}$ output for BP than for BAR may have been due to shifts in ruminal proportions of individual VFA, which have been shown to affect $\mathrm{CH}_{4}$ production. Whereas propionate formation consumes reducing equivalents, acetate and butyrate formation generate $\mathrm{H}_{2}$ for methanogenesis (Hungate, 1966; Owens and Goetsch, 1988). Acetate concentrations were greater for $\mathrm{BP}$ than for $\mathrm{BAR}$ as discussed earlier.

When ruminal NDF digestibility is decreased, greater amounts of undigested NDF pass out of the rumen and are fermented in the hind gut, resulting in increased $\mathrm{CH}_{4}$ production (Moe and Tyrrell, 1979). Because the continuous culture fermentor system simulates the rumen but not the hind gut, this may not be the most plausible explanation for the noted changes in $\mathrm{CH}_{4}$ in the current study. Rather, changes in individual VFA, specifically acetate, likely resulted in the observed difference in $\mathrm{CH}_{4}$. When the actual $\mathrm{CH}_{4}$ values were compared with the $\mathrm{CH}_{4}$ prediction equation of Owens and Goetsch (1988), which is based on VFA production $\left[\mathrm{CH}_{4}(\mathrm{mmol} / \mathrm{d})=(0.5 \times\right.$ acetate $)+(0.5 \times$ butyrate $)-$ $(0.25 \times$ propionate $)]$, the equation underpredicted $\mathrm{CH}_{4}$ for BP ( 8 and $2 \%$ for the 5 and $10 \%$ supplementation levels, respectively) and overpredicted $\mathrm{CH}_{4}$ for BAR (14 and $18 \%$ for the 5 and $10 \%$ supplementation levels of BAR, respectively). These differences were primarily due to the differences noted in acetate production among the treatments, as the acetate fermentation process provides a methyl group for methanogenesis (Ferry, 1992).

\section{Nitrogen Metabolism}

Significant supplement type $\times$ level of supplementation interactions were observed for bacterial $\mathrm{N}$ flow and efficiency with the $5 \%$ BAR and $10 \%$ BP showing the lowest values. Organic matter truly digested was not different across treatments ( mean $=82 \%$ ), thus suggesting that fermentable energy did not limit bacterial growth in the current study. It is a conceivable that individual or a combination of factors such as types of substrates (pectin versus starch), associative effects between the basal diet and substrates, fermentation patterns, or dilution of ryegrass with substrates may explain to some extent these observed interactions. For instance, Hall and Herejk (2001) fed isolated bermudagrass (Cynodon dactylon) NDF alone or in combination (60:40 ratios) with sucrose, pectin, or corn starch to mixed rumen microbial populations in vitro, and observed maximal microbial yields (measured as TCA-precipitable protein) for each substrate as starch $>$ sucrose $=$ pectin $>$ bermudagrass NDF (Hall and Herejk, 2001).

Despite fairly similar intakes of CP and RDP across treatments, the small variation in $\mathrm{N}$ input into the system when orchardgrass was a greater proportion of the treatment (at the lower supplementation levels) resulted in tendencies for increased $\mathrm{N}$ intake and $\mathrm{NH}_{3}-$ $\mathrm{N}$ concentrations in these treatments. However, these differences are not likely to be biologically important. Despite lower N intake, BAR-fed fermentors had a greater total $\mathrm{N}$ flow than BP-fed fermenters. The $89 \%$ greater dietary $\mathrm{N}$ flow for BAR than for $\mathrm{BP}$ explains the greater total $\mathrm{N}$ and $\mathrm{NAN}$ flows when $\mathrm{NH}_{3}-\mathrm{N}$ flow was similar across treatments.

\section{CONCLUSIONS}

Supplementing orchardgrass with beet pulp improved CP digestibility, reduced fiber digestibility, and increased total VFA concentration and $\mathrm{CH}_{4}$ output compared with barley-supplemented orchardgrass. Increased $\mathrm{CH}_{4}$ output with beet pulp may have negative environmental effects and must be weighed against potential benefits. Significant supplement type $\times$ level of supplementation interactions were observed for bacterial $\mathrm{N}$ flow and efficiency in fermentors fed barley at the lowest level of supplementation or beet pulp at the greatest level of supplementation. Bacterial growth was not limited by fermentable energy (similar OM truly digested in the rumen across treatments), suggesting that types of substrates (e.g., pectin vs. starch), associative effects between the basal diet and substrates, fermentation patterns, or dilution of ryegrass with substrates may explain to some extent the bacterial $\mathrm{N}$ flow and efficiency interactions. The greatest apparent CP digestibility with beet pulp without an accompanied effect on the concentration of $\mathrm{NH}_{3}-\mathrm{N}$ appears to indicate that RDP-N was efficiently captured by the microbes, as beet pulp may have provided a more synchronous supply of fermentable energy relative to orchardgrass soluble N. Further research is needed to better understand $\mathrm{N}$ use efficiency in grass-based diets supplemented with ruminally fermentable fiber sources.

\section{ACKNOWLEDGMENTS}

The authors thank J. Everhart, R. Stout, C. Dell (USDA-Agricultural Research Service) and J. Dillon (Penn State) for laboratory expertise and time contrib- 
uted to conducting this experiment. This project was partially funded by USDA-National Institute of Food and Agriculture (NIFA, Washington, DC)-Organic Agriculture Research and Extension Initiative (OREI).

\section{REFERENCES}

AOAC International. 2006. Official Methods of Analysis. 18th ed. AOAC Int., Gaithersburg, MD.

Ariza, P., A. Bach, M. D. Stern, and M. B. Hall. 2001. Effects of carbohydrates from citrus pulp and hominy feed on microbial fermentation in continuous culture. J. Anim. Sci. 79:2713-2718.

Bach, A., I. K. Yoon, M. D. Stern, H. G. Jung, and H. Chester-Jones. 1999. Effects of type of carbohydrate supplementation to lush pastures on microbial fermentation in continuous culture. J. Dairy Sci. 82:153-160.

Bargo, F., L. D. Muller, J. E. Delahoy, and T. W. Cassidy. 2002. Milk response to concentrate supplementation of high producing dairy cows grazing at two pasture allowances. J. Dairy Sci. 85:1777-1792.

Bargo, F., G. A. Varga, L. D. Muller, and E. S. Kolver. 2003. Pasture intake and substitution rate effects on nutrient digestion and nitrogen metabolism during continuous culture fermentation. J. Dairy Sci. 86:1330-1340

Brask, M., M. R. Weisbjerg, A. L. F. Hellwing, A. Bannink, and P. Lund. 2015. Methane production and diurnal variation measured in dairy cows and predicted from fermentation pattern and nutrient or carbon flow. Animal 9:1795-1806.

Carey, D. A., J. S. Caton, and M. Biondini. 1993. Influence of energy source on forage intake, digestibility, in situ forage degradation and ruminal fermentation in beef steers fed medium-quality brome hay. J. Anim. Sci. 71:2260-2269.

Coblentz, W. K., I. E. O. Abdelgardir, R. C. Cochran, J. O. Fritz, W. H. Fick, K. C. Olson, and J. E. Turner. 1999. Degradability of forage proteins by in situ and in vitro enzymatic methods. J. Dairy Sci. 82:343-354.

de Veth, M. J., and E. S. Kolver. 2001. Digestion of ryegrass pasture in response to change in $\mathrm{pH}$ in continuous culture. J. Dairy Sci. 84:1449-1457.

Dixon, R. M., and C. R. Stockdale. 1999. Associative effects between forages and grains: consequences for feed utilization. Aust. J. Agric. Res. 50:757-773.

Dušková, D., and M. Marounek. 2001. Fermentation of pectin and glucose, and activity of pectin-degrading enzymes in the rumen bacterium Lachnospira multiparus. Lett. Appl. Microbiol. 33:159-163.

El-Shazly, K., B. A. Dehority, and R. R. Johnson. 1961. Effect of starch on the digestion of cellulose in vitro and in vivo by rumen microorganisms. J. Anim. Sci. 20:268-273.

Erwin, E. S., G. J. Marco, and E. M. Emery. 1961. Volatile fatty acid analysis of blood and rumen fluid by gas chromatography. J. Dairy Sci. 44:1768-1771

Fellner, V., J. C. Burns, and D. C. Marshall. 2008. Effect of feeding corn, hull-less or hulled barley on fermentation by mixed cultures of ruminal microorganisms. J. Dairy Sci. 91:1936-1941.

Feng, P., C. W. Hunt, G. T. Pritchard, and S. M. Parish. 1995. Effect of barley variety and dietary barley content on digestive function of beef steers fed grass hay-based diets. J. Anim. Sci. 73:3476-3484.

Ferry, J. G. 1992. Methane from acetate. J. Bacteriol. 174:5489-5495.

García, S. C., F. J. Santini, and J. C. Elizalde. 2000. Sites of digestion and bacterial protein synthesis in dairy heifers fed fresh oats with or without corn or barley grain. J. Dairy Sci. 83:746-755.

Grigsby, K. N., M. S. Kerley, J. A. Paterson, and J. C. Weigel. 1992 Site and extent of nutrient digestion by steers fed a low-quality bromegrass hay diet with incremental levels of soybean hull substitution. J. Anim. Sci. 70:1941-1949.

Griswold, K. E., W. H. Hoover, T. K. Miller, and W. V. Thayne. 1996 Effect of form of nitrogen on ruminal microbes in continuous culture. J. Anim. Sci. 74:483-491.

Hafla, A. N., K. J. Soder, A. F. Brito, M. D. Rubano, and C. J. Dell. 2014. Effect of sprouted barley grain supplementation of an herbage-based or haylage-based diet on ruminal fermentation and methane output in continuous culture. J. Dairy Sci. 97:7856-7869.

Hall, M. B., and C. Herejk. 2001. Differences in yields of microbial crude protein from in vitro fermentation of carbohydrates. J. Dairy Sci. 84:2486-2493.

Hall, M. B., W. H. Hoover, J. P. Jennings, and T. K. Miller-Webster. 1999. A method for partitioning neutral detergent-soluble carbohydrates. J. Sci. Food Agric. 79:2079-2086.

Hoover, W. H. 1986. Chemical factors involved in ruminal fiber digestion. J. Dairy Sci. 69:2755-2766.

Hoover, W. H., T. K. Miller, S. R. Stokes, and W. V. Thayne. 1989 Effects of fish meals on rumen bacterial fermentation in continuous culture. J. Dairy Sci. 72:2991-2998.

Hungate, R. E. 1966. The Rumen and its Microbes. Academic Press, New York, NY

Johnson, M. C., A. A. Devine, J. C. Ellis, A. M. Grunden, and V. Fellner. 2009. Effects of antibiotics and oil on microbial profiles and fermentation in mixed cultures of ruminal microorganisms. J. Dairy Sci. 92:4467-4480.

Jones, D. I. H., and R. W. Bailey. 1972. The hydrolysis of cell wall polysaccharides from freeze-dried and oven-dried herbage by rumen and mould carbohydrases. J. Sci. Food Agric. 23:609-614.

Kellaway, R., and S. Porta. 1993. Feed concentrate supplements for dairy cows. Dairy Research and Development Corp., Victoria, Australia.

Liu, J., Y.-Y. Pu, Q. Xie, J.-K. Wang, and J.-X. Liu. 2015. Pectin induces an in vitro rumen microbial population shift attributed to the pectinolytic Treponema group. Curr. Microbiol. 70:67-74.

Marounek, M., and D. Dušková. 1999. Metabolism of pectin in rumen bacteria Butyrivibrio fibrisolvens and Prevotella ruminicola. Lett. Appl. Microbiol. 29:429-433.

Miller, B. G., and R. B. Muntifering. 1985. Effect of forage:concentrate on kinetics of forage fiber digestion in vivo. J. Dairy Sci. 68:40-44.

Miller-Webster, T., W. H. Hoover, M. Holt, and J. E. Nocek. 2002 Influence of yeast culture on ruminal microbial metabolism in continuous culture. J. Dairy Sci. 85:2009-2014

Miura, H., M. Horiguchi, and T. Matsumoto. 1980. Nutritional interdependence among rumen bacteria, Bacteroides amylophilus, Megasphaera elsdenii, and Ruminococcus albus. Appl. Environ. Microbiol. 40:294-300.

Moe, P. W., and H. F. Tyrrell. 1979. Methane production in dairy cows. J. Dairy Sci. 62:1583-1586.

Mould, F. L., and E. R. Orskov. 1984. Manipulation of rumen fluid $\mathrm{pH}$ and its influence on cellulolysis in sacco, dry matter degradation and the rumen microflora of sheep offered either hay or concentrate. Anim. Feed Sci. Technol. 10:1-14.

Mount, D. E., T. J. Steffens, D. N. Schutz, and J. C. Whittier. 2009 Fibrous and nonfibrous carbohydrate supplementation to ruminants grazing forage from small grain crops. Prof. Anim. Sci 25:139-144.

NRC. 2001. Nutrient Requirements of Dairy Cattle. 7th rev. ed. Natl Acad. Press, Washington, DC.

O'Mara, F. P., G. K. Stakelum, P. Dillon, J. J. Murphy, and M. Rath. 1997. Rumen fermentation and nutrient flows for cows fed grass and grass supplemented with molassed beet pulp pellets. J. Dairy Sci. 80:2466-2474.

Owens, F. N., and A. L. Goetsch. 1988. Ruminal fermentation. In: Church, D.C., editor. The Ruminant Animal: Digestive Physiology and Metabolism. Prentice Hall, New Jersey.pp. 145-171.

Pulido, R. G., R. Munoz, C. Jara, O. A. Balocchi, J. P. Smulders, F. Wittwer, P. Orellana, and M. O'Donovan. 2010. The effect of pasture allowance and concentrate supplementation type on milk production performance and dry matter intake of autumn-calving dairy cows in early lactation. Livest. Sci. 132:119-125.

Smith, D. 1969. Removing and analyzing total nonstructural carbohydrates from plant tissue. Wisconsin Agric. Exp. Sta. Res. Rep. 41:1.

Soder, K. J., A. F. Brito, and M. D. Rubano. 2012. Effect of incremental flaxseed supplementation of an herbage diet on methane output and ruminal fermentation in continuous culture. J. Dairy Sci. 95:3961-3969. 
Stockdale, C. R. 1999. Effects of cereal grain, lupins-cereal grain or hay supplements on the intake and performance of grazing dairy cows. Aust. J. Exp. Agric. 39:811-817.

Stockdale, C. R., A. Callaghan, and T. E. Trigg. 1987. Feeding high energy supplements to pasture-fed dairy cows. Effects of stage of lactation and level of supplement. Aust. J. Exp. Agric. 38:927-940.

Strobel, H. J., and J. B. Russell. 1986. Effect of $\mathrm{pH}$ and energy spilling on bacterial protein synthesis by carbohydrate-limited cultures of mixed rumen bacteria. J. Dairy Sci. 69:2941-2947.

Supelco. 1975. Supelco Bulletin 749E. Supelco Inc., Bellefonte, PA.

Van Soest, P. J., J. B. Robertson, and B. A. Lewis. 1991. Methods for dietary fiber, neutral detergent fiber, and nonstarch polysaccharides in relation to animal nutrition. J. Dairy Sci. 74:3583-3597.

van Vuuren, A. M., S. Tamminga, and R. S. Ketelaar. 1990. Ruminal availability of nitrogen and carbohydrates from fresh and preserved herbage in dairy cows. Neth. J. Agric. Sci. 38:499-512.

van Vuuren, A. M., C. J. Van der Koelen, H. Valk, and H. de Visser. 1993. Effects of partial replacement of ryegrass by low protein feeds on ruminal fermentation and nitrogen loss by dairy cows. J. Dairy Sci. 76:2982-2993

van Vuuren, A. M., J. Van der Koelen, and J. Vroons-de Bruin. 1986. Influence of the level and composition of concentrate supplements on rumen fermentation patterns of grazing dairy cows. Neth. J. Agric. Sci. 34:457-467.

Vibart, R. E., S. P. Washburn, V. Fellner, M. H. Poore, J. T. Green Jr., and C. Brownie. 2007. Varying endophyte status and energy supplementation of fresh tall fescue in continuous culture. Anim. Feed Sci. Technol. 132:123-136.

Wales, W. J., E. S. Kolver, and A. R. Egan. 2009. Digestion during continuous culture fermentation when replacing perennial ryegrass with barley and steam-flaked corn. J. Dairy Sci. 92:189-196.

Wales, W. J., E. S. Kolver, P. L. Thorne, and A. R. Egan. 2004. Diurnal variation in ruminal $\mathrm{pH}$ on the digestibility of highly digestible perennial ryegrass during continuous culture fermentation. J. Dairy Sci. 87:1864-1871.

Weller, R. A., and A. F. Pilgrim. 1974. Passage of protozoa and volatile fatty acids from the rumen of the sheep and from a continuous in vitro fermentation system. Br. J. Nutr. 32:341-351.

Yang, C. M. J., and G. A. Varga. 1989. Effect of three concentrate feeding frequencies on rumen protozoa, rumen digesta kinetics, and milk yields in dairy cows. J. Dairy Sci. 72:950-957.

Zhao, X. H., C. J. Liu, Y. Liu, C. Y. Li, and J. H. Yao. 2013. Effects of replacing dietary starch with neutral detergent-soluble fibre on ruminal fermentation, microbial synthesis and populations of ruminal cellulolytic bacteria using the rumen simulation technique (RUSITEC). J. Anim. Physiol. Anim. Nutr. (Berl.) 97:1161-1169.

Zinn, R. A., and F. N. Owens. 1986. A rapid procedure for purine measurement and its use for estimating net ruminal protein synthesis. Can. J. Anim. Sci. 66:157-166. 